\title{
Execução de sentença na pendência de recur- sos de revista e extraordinário
}

\author{
Luís Eulálio de Buèno Vidigal \\ Catedrático de Direito Judiciário Civil na \\ Faculdade de Direito da Universidade de \\ São Paulo.
}

1. Segundo o artigo 882 do Código de Processo Civil, são exequíveis as sentenças:

I, quando transitadas em julgado;

II, quando recebido o recurso no efeito sòmente devolutivo.

Dispõe o artigo seguinte que a execução provisória não abrangerá os atos que importarem alienação de domínio, nem autorizará, sem caução idônea, o levantamento de depósito em dinheiro.

Por outro lado, segundo o $\S 10^{\circ}$ do artigo 808 dêsse Código, o recurso extraordinário e a revista não suspendem a execução da sentença.

Indaga-se, em face dêste último texto, se é possível restringir, pela exigência de caução, a execução de sentença contra a qual se interpuseram ambos os recursos.

2. Muitos processualistas nacionais e estrangeiros, por curiosa inadvertência, costumam referir-se apenas à apelação, quando tratam dos efeitos devolutivo e suspensivo dos recursos. Assim, entre outros, Gabriel de Rezende Filho, Curso III, 1946, pág. 95; João Monteiro, Theoria, 3. ${ }^{\circ}, 1905$, pág. 157; Ramalho, Praxe, 1869, pág. 552; Glasson, Traité, 
III, 1929, págs. 341 e 343; Chiovenda, Istituzioni, II, 1936, pág. 550; Wetzell, System, 1878, pág. 729.

Não há motivo para essa limitação. Como muito bem ensina Pontes de Miranda,

"os recursos ou são de plena devolução da matéria discutida, ou apenas de certa parte da matéria. Quando se diz que o agravo sòmente devolve a parte em que houve o gravame, ao passo que a apelação pode devolver tudo, relembra-se diferença que hoje já não é de aceitar-se, em tôda a sua abrangência. Se é certo que a apelação ainda pode ter devolução cabal total (isto é, de todo o efeito), ao conhecimento do tribunal para o qual se apelou, o agravo muitas vêzes tem a mesma função, devido a certa política jurídica mais pragmatista e menos intelectualista, que passou ao conhecimento dos tribunais de agravo de recursos que eram objeto de apelação. Há recursos, porém, que mantêm devolução ainda mais restrita e resistem às influências daquela política utilitária e oportunista a que nos referimos. É o caso da revista, do prejulgado, e dos embargos aos acórđãos quando tenham intuito de infringências ou de decretação de nulidade (embargos de nulidade e infringentes do julgado). E o do recurso extraordinário." (Comentários, vol. 5. pág. 19).

Seabra Fagundes, igualmente, esclarece que

"o efeito devolutivo pode ser parcial ou total, o que depende da vontade do recorrente ou da natureza do recurso" (Recursos ordinários, pág. 185).

Na doutrina alemã, também se costuma cogitar dos efeitos suspensivo e devolutivo a propósito dos recursos em 
geral e não apenas a propósito da apelação (Cf. Schönke, Zivilprozessrecht, 1949, pág. 33; Rosenberg, Lehrbuch, 1929, pág. 438).

3. O efeito suspensivo impede que a sentença seja executada; do efeito devolutivo decorre a competência -de tribunal superior para conhecer da causa.

Um e outro podem ser mais ou menos intensos. A apelação tem ordinàriamente efeito suspensivo ilimitado: impede qualquer ato de execução. $O$ efeito devolutivo é sempre limitado; as questões de fato não propostas na instância inferior sòmente poderão ser suscitadas no processo de apelação, se as partes provarem que deixaram de fazê-lo por motivo de fôrça maior.

Há apelações que suspendem a execução mas não impedem a liquidação na pendência do recurso (Código de Processo Civil, artigo 830, $\S 1^{\circ}$ ).

A vontade das partes também pode levar à limitação do efeito devolutivo (Código de Processo Civil, artigo 811). Essas considerações são feitas para se ter presente que o fato de terem alguns recursos ef eito devolutivo menos amplo não significa que não tenham sido recebidos apenas no efeito devolutivo. A revista e o recurso extraordinário também tem efeito apenas devolutivo. Diferem da apelação recebida sòmente com êsse efeito apenas no sentido em que a apelação tem efeito devolutivo amplo e aquêles dois recursos o têm limitado.

4. Hoje, salvo disposição expressa da lei, tôdas as apelações têm efeito suspensivo. Mas nem sempre foi assim. Quem ler a Praxe Brasileira, de Ramalho, no capítulo dos efeitos do recebimento da apelação, verá que essa matéria era, antes dos códigos de processo, extremamente controvertida. Basta ver o princípio geral enunciado à pág. 552: 
"Em regra tôda a apelação recebe-se $\mathrm{\epsilon m}$ ambos os efeitos; mas, por exceção, receந̄em-se no efeito devolutivo por disposição expressa da lei ou por praxe, as apelações" etc.

Da incerteza então reinante sôbre o assunto veio o hábito de determinar-se ao Juiz que declare os efeitos em que recebe a apelação, como se êle tivesse o poder de precisar arbitràriamente êsses efeitos (v. o artigo 826,

"o juiz, declarando os efeitos em que a recebe", o artigo 829,

"recebida a apelação no efeito sòmente devolutivo", o artigo 830 ,

"serão recebidas no efeito sòmente devolutivo",

o artigo 831,

"salvo se a apelação houver sido recebida no efeito sòmente devolutivo",

e o artigo 882,

"quando recebido o recurso no efeito sòmente devolutivo.")

A insistência do Código em aludir ao ato em que o Juiz declara os efeitos em que recebe a apelação, poderia levar à suposição de que lhe incumbe discricionàriamente precisar êsses efeitos.

É claro que, nos tópicos citados, o Código deveria ter dito: 
"o juiz, declarando os efeitos da apelação", "tendo a apelação sòmente ef eito devolutivo", "terão sòmente efeito devolutivo"

e

"salvo se se tratar de apelação provida apenas de efeito devolutivo".

A propósito dos demais recursos, o Código, por influência da técnica seguida pelos autores há pouco citados, jamais falou de efeito devolutivo.

5. Vem daí, talvez, o êrro em que têm incidido tantos julgados, de não considerarem, para aplicação do artigo 882, II, como recebidos apenas no efeito devolutivo os recursos de revista e extraordinário. Em nenhum tópico disse o Código que êles seriam recebidos apenas no efeito devolutivo. Sendo, porém, dois os efeitos dos recursos, suspensivo (amplo ou limitado) e devolutivo (integral ou parcial), tanto podia o Código dizer,

"a revista e o recurso extraordinário serão recebidos sòmente no ef eito devolutivo",

como

"a revista e o recurso extraordinário não terão efeito suspensivo"

ou, finalmente,

"o recurso extraordinário e a revista não suspendem a execução da sentença"

Foi esta última a redação adotada pelo Código. Em nenhum outro dispositivo legal se declararam os efeitos dêsses recursos. $0 \S 10^{\circ}$ do artigo 808 tem, em relação à 
revista e ao recurso extraordinário, exatamente o mesmo sentido e a mesma compreensão do artigo $829,2 .^{a}$ parte, em relação à apelação recebida apenas no efeito devolutivo.

6. Vejamos e critiquemos alguns dos fundamentos em que se baseiam os propugnadores da tese de que é definitiva, e não provisória, a execução de sentença de que pendem recurso de revista e recurso extraordinário.

O recurso extraordinário — diz um acórdão do Tribunal de São Paulo - "não suspende a execução da sentença. E apenas de sentença passada em julgado é êle admitido". (Rev. dos Trib., vol. 177, pág. 339్; incidindo no mesmo êrro, acórdão do Supremo Tribunal Federal, vol. 152, pág. 170, da mesma Revista).

É certo que êle não suspenda a execução dá sentença; errôneo, que só se admita contra decisão passada em julgado. E é precisamente por não ter transitado em julgado que a sentença só pode executar-se provisòriamente.

Lê-se realmente em Pimenta Bueno que coisa julgada significa a decisão formulada por uma sentença definitiva, que já não pende do recurso de apelação; e coisa soberanamente julgada se diz aquela que não só não pende mais do recurso de apelação, porém nem ainda da revista ou ação rescisória ou de nulidade, por não ser no caso dela admitida pela lei (Apontamentos sôbre as formalidades do processo civil, 1911, pág. 200).

Com base nessa opinião de Pimenta Bueno, afirmou Virgilio Sá Pereira que a sentença passa em julgado apesar do recurso extraordinário. Depois da vigência do Código Civil, entretanto, essa tese é insustentável. Não há rảzão, no Brasil, para a distinção entre recursos ordinários e extraordinários, invocada por alguns acórdãos, para fundamentar a tese da definitividade da execução da sentença de que pende revista ou recurso extraordinário (v. voto do Desembargador Paulo Colombo, que depois, em embargos, se tornou vencedor, na Revista dos Tribunais, vol. 153, pág. 592). 
Em França, a distinção entre recursos ordinários e extraordinários tem base legal:

"Une autre classification ayant sa base dans la loi, distingue les voies de recours ordinaires et les voies de recours extraordinaires. Les voies de recours extraordinaires ne sont ouvertes que dans des cas limitativement déterminés par la loi, tandis que les voies de recours ordinaires sont admises sans aucune limitation des cas d'ouverture. Il en résulte que, dans les voies des recours ordinaires, le juge est saisi du procès tout entier, dans les mêmes conditions que l'ont été les premiers juges, tandis que les pouvoirs du juge saisi par une voie extraordinaire sont limités au seul examen de la question soulevée par le rècours. Les voies de recours ordinaires sont: l'opposition et l'appel. Toutes les autres sont des voies de recours extraordinaires. La distinction présente des intérêts. Les voies de recours ordinaires sont en principe suspensives, c'est à dire qu'elles arrêtent l'execution du jugement, à moins que le tribunal n'ait ordonné l'exécution provisoire. Il n'en est pas de même des voies de recours extraordinaires; en principe elles n'empêchent pas la partie que a gagné son pròces de poursuivre l'exécution du jugement. (René Morel, Traité Élémentaire de Procédure Civile, 1932, pág. 629).

E, a propósito da cousa julgada:

"Suivant la terminologie généralement employée en France, la décision qui n'est plus susceptible d'une voie de recours ordinaire passe en force de chose jugée, alors même qu'ne voie de recours extraordinaire est encore ouverte contre elle". (id., ib., pág. 602). 
Também na Itália, o Código de Processo Civil de 1865, sob a vigência do qual escreveu Chiovenda, geralmente citado pelos acórdãos que consideram definitiva a execução de sentença de que pende o recurso de revista ou o extraordinário, dispunha expressamente:

"I mezzi per impugnare le sentenze sono ordinari o straordinari. I mezzi ordinari sono l'opposizione e l'appellazione"

70 direito brasileiro não consagrou a distinção entre recursos ordinários e extraordinários. Ao contrário, o Projeto de Código Civil de Clovis Bevilaqua dizia no artigo $5 .^{\circ}, \S 3 .^{\circ}$, da Introdução:

"Considera-se cousa julgada a decisão judiciária contra a qual não cabe mais recurso ordinário às partes."

O Senado, adverte Matos Peixoto, eliminou do dispositivo em questão o adjetivo "ordinário" precisamente para não se supôr que as decisões sujeitas ao recurso extraordinário transitem em julgado (Recurso Extraordinârio, pág. 270).

A lei 3.238, de $1 .^{\circ}$ de Agôsto de 1957, restabelecendo o texto "chama-se coisa julgada ou caso julgado a decisão judicial de que já não caiba recurso", da primitiva Introdução ao Código Civil, absolutamente não distingue entre recursos ordinários e extraordinários.

8. Portanto, enquanto pendem o recurso de revista e o recurso extraordinário, não se pode, no Brasil, em face do atual texto do $\S 3 .^{\circ}$ do artigo $6 .^{\circ}$ da Lei de Introdução ao Código Civil, dizer que uma decisão transitou em julgado.

Participa dessa opinião o próprio Desembargador Paulo Colombo no mencionado voto em que se baseou a corrente defensora da definitividade da execução. "Se a sentença com recurso recebido no efeito devolutivo fôsse, de acôrdo 
com a distinção doutrinária acima dada, sentença passada em julgado, transitada em julgado, desnecessário seria o n. ${ }^{\circ}$ II dêste artigo (882). Desde que êle foi preceituado, essa sentença, embora exequível, não é transitada em julgado. Como tal só pode ser considerada a que não possa ser modificada em virtude de recurso, de qualquer natureza, mesmo recebido só no efeito devolutivo." (Rev. dos Tribunais, vol. 153, pág. 593).

Para poder concluir pela definitividade da execução, precisou recorrer êsse ilustre magistrado à distinção entre recursos ordinários e extraordinários, que não existe no Brasil, e que, na França ou na Itália, tem efeitos relevantes para a execução, em virtude de expressas disposições legais.

9. Argumenta o citado voto do Desembargador Paulo Colombo: "Se a execução fôsse provisória o legislador processual teria prescrito no $\S 1 .^{\circ}$ do artigo 808 , tal como fêz em relação à apelação recebida só com efeito devolutivo, no artigo 829:

"Admitido o recurso extraordinário ou a revista, o recorrido poderá promover, desde logo, a execução provisória de sentença, que correrá nos autos suplementares."

Absolutamente. A redação do $\S 1 .^{\circ}$ do artigo 808 tem precisamente o mesmo alcance da que se deu à segunda parte do artigo 829. Diz-se que êste fala, e aquêle não, em "execução provisória da sentença" A aceitar-se essa argumentação, até a execução de sentença de que pende apelação recebida sòmente no efeito devolutivo seria definitiva e não provisória, porque o artigo 882 também não fala em execução provisória. Diz apenas: Serão exequíveis as sentenças quando recebido o recurso no efeito sòmente devolutivo. Deveria, então, ter dito:

"Serão exequíveis, definitivamente, as sentenças quando transitadas em julgado e, provisòria- 
mente, quando recebido o recurso no ef eito sòmente devolutivo."

E se o artigo 882, II, quizesse referir-se apenas à apelação, e não aos demais recursos que não têm efeito suspensivo, não teria empregado a expressão genérica "recurso" e, sim, teria dito pura e simplesmente:

II - quando recebida a apelação no efeito sòmente devolutivo.

10. Acrescentemos, por último, aos argumentos que expendemos, favoráveis à tese de que a execução de sentença de que pende recurso extraordinário e revista, é provisória e não definitiva, o argumento de autoridade.

Os dois maiores mestres do processo civil brasileiro, Pontes de Miranda e Enrico Tullio Liebman, opinaram sem hesitações por essa solução.

Disse o primeiro:

“O recurso extraordinário não suspende a execução do julgado, aí provisória; e, provisória, têm-se de respeitar os princípios, inclusive o artigo 883 , III. Sem razão, a dispensa de caução se há recurso de revista ou se há o recurso extraordinário". (Comentários, vol. VI, 1949, pág. 42).

E adiante:

"A respeito de caução, têm-se procurado distinguir dos outros recursos Tapelação, agravo, embargos de nulidade e infringentes do julgado) de revista e o recurso extraordinário; porém isso não está na lei, nem se explica, a despeito da insistência de tal jurisprudência. Não há execução definitiva se cabe qualquer recurso e, sendo, portanto, provisória a execução, o artigo 883, 
III, tem de incidir. Não há execução definitiva se pende recurso; e não há qualquer diferença entre as execuções provisórias por motivo de distinção entre os recursos: recurso de efeito suspensivo, nenhuma execução; recurso sem efeito suspensivo, permitida, não obstante e apenas, a execução provisória."

Mais incisiva é ainda, talvez, a opinião de Liebman:

"Estabeleceu a lei a distinção entre execução definitiva e provisória e entendeu por definitiva a execução da sentença transitada em julgado, isto é, irretratável. Provisória é tôda execúção que não é definitiva, quer dizer, que não tem por fundamento uma sentença irretratável. De um "tertium genus", representado por uma execução definitiva, embora baseada em sentença recorrível, não há na lei qualquer indício. Não existem razões práticas que possam fazer preferir solução diferente. Os inconvenientes decorrentes da espera na realização dos atos culminantes da exécução, depois de seguro o juízo, se compensam com a vantagem de evitar o perigo de não se poder restabelecer o estado anterior, na hipótese de ser provido o recurso". (Estudos sôbre o processo civil brasileiro, pág. 97).

11 Podemos, pois, concluir com Liebman:

"A execução da sentença, na pendência de recurso extraordinário e de revista, deve ser considerada provisória, com as regras e restrições do artigo 883 do Código de Processo Civil” (id. ib.). 